\title{
Promoting the Values of Pancasila for Elemntary School Through Interactive Learning Media: Responding to Challenges and Responses of Citizenship Education in a Pandemic Covid-19
}

\author{
Yayuk Hidayah ${ }^{1, *}$ Suyitno Suyitno ${ }^{2,}$ Meiwatizal Trihastuti ${ }^{3,4}$ \\ ${ }^{1,2}$ Universitas Ahmad Dahlan Yogyakarta \\ ${ }^{3}$ STKIP Pasundan \\ ${ }^{4}$ IAIN Ponorogo \\ *Corresponding author.Email: yayuk.hidayah@pgsd.uad.ac.id
}

\begin{abstract}
The purpose of this study was to analyze and study about promoting the values of Pancasila for Elementary Schools through interactive learning media. This study was also carried out to answer the challenges and responses of Citizenship Education in the Covid-19 pandemic. This research was literature study. The results of the study showed that promoting the values of Pancasila for Elementary Schools through interactive learning media in the Covid-19 pandemic was as 1) an effort to foster digital character for the digital native generation, 2) the existence of interactive learning media became a support system in promoting the values of Pancasila for Elementary Schools, and 3) interactive learning media could be an instrument in realizing a digital native generation who has ideological awareness. This study concluded that promoting the values of Pancasila for elementary schools using interactive media was the correct step in learning Citizenship Education in Elementary Schools. The study recommended that promoting the values of Pancasila for Elementary Schools needed to be done continuously, because it will be widely shared with the ideological awareness of students in Elementary Schools.
\end{abstract}

Keywords: Citizenship Education, Covid-19, Pancasila, Promoting Values.

\section{INTRODUCTION}

Promoting the values of Pancasila for Elementary Schools through interactive learning media is one of the important things in introducing the meaning of the state ideology to the younger generation, including the Indonesian. [1] shows that ideology is related to how and what a person does. Idealistic intelligence is important for the younger generation [2]. Promoting the values of Pancasila for Elementary Schools is one of the responses in Citizenship Education in the vortex of information technology and in the situation of the Covid-19 pandemic.

The value of Pancasila for Elementary Schools through interactive learning media is one of the ways to maintain the existence of the state ideology for elementary schools. A study has resulted that [3] in the first grade of elementary school they already have knowledge of politics. Other research by [4] results in that the concept of citizenship and opinion serves as a resource for civic action. This shows that what is experienced by students, including elementary school students, can become meaningful learning for them.

MInteractive learning media allows students to respond to learning not only through voice but also through video and voice. [5] interpret media in learning as an intermediary tool in learning. A study has resulted [6] feasible and effective for use in junior high school. Therefore, the use of interactive media in promoting the values of Pancasila for Elementary Schools is deemed appropriate.

Furthermore, the use of interactive learning media becomes an offer and concrete solutions to the problems of ideological education for elementary schools. [7] argued that the development of a national identity requires a tool or intermediary. Promoting the values of Pancasila for Elementary Schools, in this case, is more about the initial construction of citizens in terms of ideological education.[8] In his ethnographic study of the nature and context of expression of children, it is shown that children have prevalence when playing and learning. 
This study is evidence that children have dynamics in playing and learning.

Pancasila contains moral values and norms for all Indonesian citizens, including elementary schools. [9] emphasized that Indonesia's existence in the flow of globalization requires the Indonesian to preserve the values of Pancasila as the state ideology, so that it becomes a guide in the lives of citizens. [10] argued that strengthening the cultural spec is important in the sustainability of a nation. Therefore, preserving the values of Pancasila for Elementary Schools through interactive learning media is a breakthrough in Citizenship Education in the midst of globalization and in the situation of the Covid-19 pandemic.

The pandemic Covid-19 has had various impacts on human life. In elementary school learning, [11] He noted that in the situation of the Covid-19 Pandemic, there was a need for renewal and innovation for learning in primary schools. [12] informing that the Coronavirus (COVID19) pandemic has resulted in schools switching to a distance learning model. It is in this context of distance learning that it becomes a joint work on how to introduce the values of Pancasila to Elementary Schools. Based on the problems that the researcher has presented, the focus of the study was how to promote the values of Pancasila for elementary schools through interactive learning media.

\section{METHOD}

We used a critical descriptive qualitative method by emphasizing critical analysis with a library research approach. The qualitative use was based on opinion [13] which states that qualitative research emphasized on description. We also used a reference source in the form of books, notes and research results in accordance with the explanation. [14] states that in library research used literature in the form of books, notes and research results that had a connection with promoting the values of Pancasila for Elementary Schools through interactive learning media: answering the challenges and responses of citizenship education in the Covid-19 pandemic. This study was based on an opinion [15] which stated that the library research data collection was interpreted to produce a thesis and anti-thesis. There were four (4) stages in this study [16], namely 1) preparation of tools; (prepared writing instruments for notes), 2) prepared a working bibliography, 3 ) arranged time (determining the time to review the study), 4) recorded and made a research report.

\section{RESULT AND DISCUSSION}

Based on the critical analysis, we could identify that in promoting the values of Pancasila for Elementary Schools through interactive learning media, there were several theses, namely 1) promoting Pancasila values for Elementary school was an effort to foster digital character for the digital native generation, 2) interactive learning media became a support system in promoting Pancasila values, 3) interactive learning media could be an instrument in realizing a native digital generation that had ideological awareness.

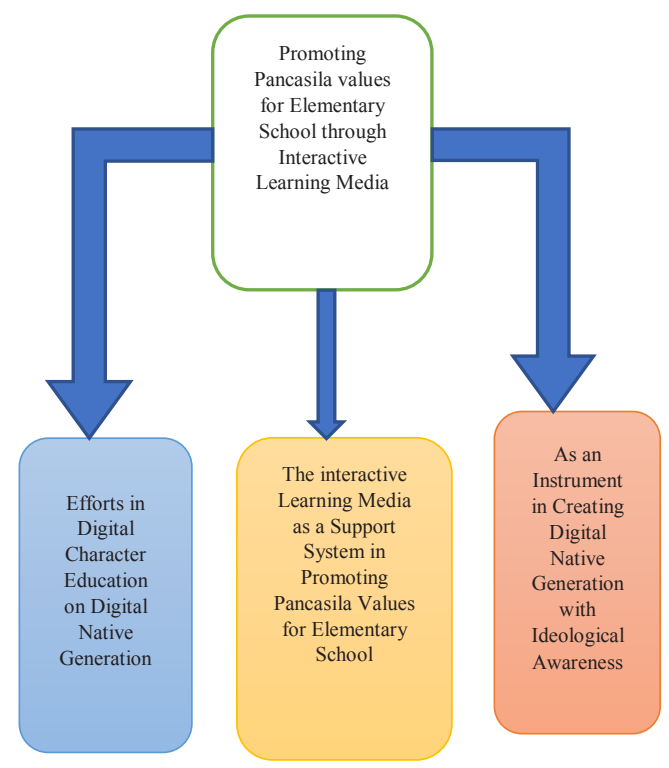

Figure 1: Chart promoting the values of Pancasila for Elementary Schools through interactive learning media

1) Promoting the values of Pancasila for Elementary Schools as an effort to foster digital character for the digital native generation.

Based on Figure 1, promoting the values of Pancasila for Elementary Schools was an effort to foster digital character for the digital native generation. [17] This meant that digital native was a generation that had known the internet since the age of 24 years. The digital native was a generation that was born when the adoption of digital technology. [18] states that digital native was the internet generation that was born after the 1980s and their world is surrounded by the use of technological devices and digitization. Thus, elementary school students became one of the digital native generations where they received the impact of technological devices and digitization [19], so that it can promote the values of Pancasila for Elementary Schools in line with the development of digital characters in digital native.

The challenge of Citizenship Education in the Covid19 pandemic required a formulation in internalizing digital characters in digital native, considering that the use of technological devices was inevitable in various fields of human life. [20] stated that in the digital era, human engagement activities cannot be separated from the use of technology. Therefore, for elementary schools to promote the values of Pancasila was one of the ideas in reducing the ideological crisis in the younger 
generation. [21] argues that the abstract power of ideological power influences responses to crises and in collaborative problem-solving practices. Fostering digital characters for the digital native generation through promoting Pancasila values for elementary schools, the most important thing was to emphasize and strengthen Pancasila values, so that they were inherent and could be consumed by students in elementary schools. [22] stated that it is important to think about the diversity that citizenship can make, so that citizens can position themselves as a smart and wise generation in the use of technology which will then be reflected in their digital character.

The heterogeneity of the Indonesian makes the values of Pancasila as a guide for the life of the nation. [23] states that using a historical approach to Indonesian society has provided a logical understanding of the heterogeneity of Indonesian. [24] states that managing a diverse society is difficult. In terms of the meaning of Pancasila values in the Covid 19 Pandemic situation, it can be reflected in the pride of their identity as an Indonesian citizen in surfing in the digital world, this is in accordance with the statement [25] which shows that the character dimension is effective in forming positive equity.

Digital characters For Elementary Schools, efforts are made so that students in Elementary Schools do not only memorize the values of Pancasila but can also interpret them in their digital behavior as the digital native of Indonesian society. Quoting from Kompas.com [26] it was informed that the latest report on the Digital Civility Index (DCI) showed that Indonesian netizens were in the lowest rank in Southeast Asia or most disrespectful in Southeast Asia. Although the results of these studies had varied responses, we argued that by promoting Pancasila values for Elementary Schools was one of the efforts in fostering digital character for the digital native generation.

Fostering digital characters for Indonesia's native digital generation through promoting the values of Pancasila for Elementary Schools would be able to provide knowledge on the formation of citizens' attitudes through meaningful learning in the Covid-19 pandemic situation. [27] explains that the responses to digital privacy scenarios showed how the micropolitics dimension of human ability identifies the efficient use of digital data. Therefore, promoting the values of Pancasila for elementary schools could not be separated from efforts in the context of fostering the younger generation regarding state ideology in the midst of the rapid flow of information technology.

2) The existence of interactive learning media as a support system in promoting the values of Pancasila for Elementary Schools

Based on the results of the study, promoting the values of Pancasila for elementary schools by using interactive learning media to became a support system in promoting the values of Pancasila. [28] states that there is adaptation in civic science in the COVID-19 pandemic. The existence of interactive learning media in promoting the values of Pancasila for elementary schools has a correlation in maintaining understanding and knowledge of state ideology.

The interactive media of learning in Figure 1 became a support system in promoting Pancasila values towards students' cognitive. A study has resulted [29] that in the interaction of children with the tablet they identified it as a game. Then, [30] asserts that metadata is the main foundation for converting aspects of functionality in information source tools. This supporting system could also be an enlighten on students' national insight, so that they could reposition as Indonesian citizens. [31] states that in the flow of social media marketing and management literature, space and place are implicitly related. In implementing interactive learning media, it has an important meaning in encouraging changes in message delivery in promoting Pancasila values for elementary schools.

Promoting the values of Pancasila for Elementary Schools through interactive learning media basically focuses on the goal of mastering skills as a citizen in accordance with the values of Pancasila. [32] states that in today's digital era, data security is a major obstacle in ensuring security. As stated in the statement, the interactive learning media expected a change in the learning perspective of students in terms of Pancasila values for elementary schools. The interactive learning media was a pressure point in fostering fun learning at the elementary school level, especially in terms of education regarding state ideology. [33] demonstrates that digital inequality is actively improving currently. The development of the learning media paradigm could maintain and preserve the existence of the meaning of learning about the values of Pancasila in students.

In the concept of interactive learning media, the use of technology was intended to describe learning material. [34] stated that in interactive learning, the existence of 
interactive was an important aspect of the research results [35] found that diversity is positively related to national innovation. In this context, creating two-ways communication in learning promotes the values of Pancasila for Elementary Schools and become a support system to facilitate the delivery of material, practice and evaluation in learning Pancasila values for elementary schools.

3) Interactive learning media as an instrument in realizing a digital native generation with their ideological awareness

Figure 1 illustrated that promoting the values of Pancasila for Elementary Schools, interactive learning media could be an instrument in realizing a native digital generation that had ideological awareness. [36] states that differences in political consciousness will result in heterogeneity among citizens. Promoting the values of Pancasila for Elementary Schools was a form of learning that emphasized several aspects, namely 1) providing citizenship knowledge, 2) providing opportunities to acquire civic skills that are in accordance with the nation's philosophy, and 3) producing a good attitude to life among citizens. Based on the emphasis on several aspects in promoting the values of Pancasila for elementary schools, the goal was to prepare smart and good citizens. [37] states that becoming a citizen is ultimately about how-to live-in society. This statement focuses on the meaning of how to behave as citizens in their daily lives.

Interactive media was an instrument in creating a generation that had ideological awareness. [38] argues that the literature on citizenship has focused on the practice of citizenship, and [38] suggests expanding ideas as an act of self-expression. Creating a generation that has ideological awareness requires the development of community resources that include material and nonmaterial dimensions. In a sense, interactive media becomes an instrument in realizing a generation that has ideological awareness as an attempt at symbolic internalization (the ideology of the state).

Having ideological awareness for citizens can position citizens as a civilized citizen. [39] argues that the theory of citizenship explicitly or implicitly emphasizes a separate concept in the metaphor of citizenship. Ideological awareness for citizens is a side of recognition and pride in national identity. This pride is a provision for the Indonesian in the materiality of the nation's heritage. Interactive media is an instrument in Civic Education in elementary schools in realizing citizens who have good citizen skills. [40] states that increasing Civic Education is a means of education regarding public awareness. [41] suggests that citizenship should be seen not as a status, but also as a capacity that emerges in daily material interactions and across the spectrum of civic activity. To implement this, interactive media is a consistent instrument in creating ideological awareness among citizens.

\section{CONCLUSION}

Based on the critical analysis, we could conclude several things, namely 1) promoting values of Pancasila for Elementary Schools was an effort to foster digital character for the digital native generation, 2) the interactive learning media was a support system in promoting the values of Pancasila for Elementary Schools, and 3) interactive learning media could be an instrument in realizing a digital native generation who have ideological awareness. Furthermore, through this study, we recommended that promoting the values of Pancasila for elementary schools needed to be carried out continuously, because it would be widely shared with the ideological

\section{REFERENCES}

[1] R. T. Knowles, "Ideology In The Schools: Developing The Teacher's Civic Education Ideology Scale Within The United States," Educ. Citizsh. Soc. Justice, Vol. 14, No. 3, Hal. 260-278, Okt 2018.

[2] Y. Hidayah, M. Trihastuti, Dan D. A. Dewie, "Kecerdasan Berideologi Calon Guru Pendidikan Sekolah Dasar Melalui Pendidikan Pancasila," J. Al Qiyam, Vol. 1, No. 2, Hal. 74-82, 2020.

[3] A. Goetzmann, "Elementary School Children's Political Knowledge," Am. Behav. Sci., Vol. 61, No. 2, Hal. 238-253, Feb 2017.

[4] K. Thorson, "What Does It Mean To Be A Good Citizen? Citizenship Vocabularies As Resources For Action," Ann. Am. Acad. Pol. Soc. Sci., Vol. 644, No. 1, Hal. 70-85, Okt 2012.

[5] A. Arsyad, Media Pembelajaran. Jakarta: Pt. Raja Grafindo Persada., 2011.

[6] A. A. Candra Dan M. S. Masruri, "Pengembangan Multimedia Interaktif Dengan Pendekatan Saintifik Untuk Pembelajaran Pkn Smp," Harmon. Sos. J. Pendidik. Ips, 2015.

[7] A. A. Candra, K. Suryadi, S. Nurbayani, Dan Rahmat, "Infrastructure Digital Citizenship As A Reinforcement Of National Identity," Int. J. Innov. Sci. Res. Technol., 2021.

[8] C.-H. Lum Dan P. Shehan Campbell, "The Sonic Surrounds Of An Elementary School," J. Res. Music 
Educ., Vol. 55, No. 1, Hal. 31-47, Apr 2007.

[9] A. P. Asmaroini, "Menjaga Eksistensi Pancasila Dan Penerapannya Bagi Masyarakat Di Era Globalisasi," Jpk J. Pancasila Dan Kewarganegaraan, Vol. 1, No. $2,2017$.

[10] K. Huda Dan Y. A. Feriandi, "Pendidikan Konservasi Perspektif Warisan Budaya Untuk Membangun History For Life," Sos. Polit. Hum., 2018.

[11] Y. Hidayah, L. Halimah, M. Trihastuti, D. A. Dewie, Y. A. Feriandi, Dan D. Dianasari, "How Did Prospective Elementary School Teacher Learn Citizenship Education During The Pandemic Covid-19 In Indonesia?," Ijeri Int. J. Educ. Res. Innov., Vol. 15, Hal. 373-387, 2020.

[12] P. M. Hash, "Remote Learning In School Bands During The Covid-19 Shutdown," J. Res. Music Educ., Vol. 68, No. 4, Hal. 381-397, Des 2020.

[13] Sugiyono, Metode Penelitian Kuantitatif, Kualitatif Dan R\&D. Bandung: Afabeta, 2011.

[14] I. Hasan, Analisis Data Penelitian Dengan Statistik. Jakarta: Bumi Aksara, 2008.

[15] \& S. Abdurrahman, H., Metode Penelitian Deskriptif. Jakarta: Rineka Cipta, 1999.

[16] M. Zed, Metode Peneletian Kepustakaan. Jakarta: Yayasan Obor., 2008.

[17] M. Prensky, "Digital Natives, Digital Immigrants Part 1," Horiz., Vol. 9, No. 5, Hal. 1-6, Jan 2001.

[18] M. Hill, Yearbook Of Science And Technology. Mcgraw-Hill: Books, 2001.

[19] J. Smith, Z. Skrbis, Dan M. Western, "Beneath The 'Digital Native' Myth: Understanding Young Australians' Online Time Use," J. Sociol., Vol. 49, No. 1, Hal. 97-118, Mar 2012.

[20] Y. Hidayah, Disertasi: Pengembangan Model Belajar Keterlibatan (Mbk) Untuk Memperkuat Partisipasi Politik Dan Civic Engagement Warga Negara Muda Di Era Digital (Diterbitkan). Bandung: Universitas Pendidikan Indonesia., 2020.

[21] E. Mastio Dan K. Dovey, "Power Dynamics In Organizational Change: An Australian Case," Int. J. Sociol. Soc. Policy, Vol. 39, No. 9/10, Hal. 796811, Jan 2019.

[22] J. V. A. Cabañes, “A Commentary On The Special Issue Performance And Citizenship: Challenging Populist Political Performances Through Citizenship As Performance?," Int. J. Cult. Stud., Vol. 22, No. 5, Hal. 706-715, Mei 2019.

[23] I. G. S. Astra, "Pluralitas Dan Heterogenitas Dalam
Konteks Pembinaan Kesatuan Bangsa," J. Kaji. Budaya, Vol. 10, No. 20, 2014.

[24] S. Amin, "Diversity-Development Nexus: Why Determine Economic Development Without Diversity? A Comparative Analysis Between Developed And Developing Countries," Soc. Bus. Rev., Vol. 16, No. 1, Hal. 134-150, Jan 2021.

[25] J. H. Lee, J. Jun, J. Park, J. W. Yoo, Dan H. Park, "The Role Of Characters Featured On Digital Stickers In Forming Usage Intention: Internet-Only Banks In Korea," Asia Pacific J. Mark. Logist., Vol. Ahead-Of-P, No. Ahead-Of-Print, Jan 2021.

[26] B. K. Dewi, "Netizen Indonesia Paling Tidak Sopan Se-Asia Tenggara, Pengamat Sebut Ada 3 Faktor Penyebab," Kompas.Com, 2021.

[27] A. Watson Dan D. Lupton, "Tactics, Affects And Agencies In Digital Privacy Narratives: A Story Completion Study," Online Inf. Rev., Vol. 45, No. 1, Hal. 138-156, Jan 2021.

[28] Y. Hidayah, D. A. Dewi, Dan M. Trihastuti, "The Adaptation Of Scientific Reasoning Of Prospective Teachers For Primary Education In The Perspective Of Civic Science," J. Civ. Media Kaji. Kewarganegaraan, 2021.

[29] I. Fróes, “The Digital Play Experience Taxonomy (Dpet): Mapping And Categorising The Digital Play Experience," In Young Children's Play Practices With Digital Tablets, Emerald Publishing Limited, 2019, Hal. 77-103.

[30] R. Fox, "From Cuneiform To Digital Text Encodings," Oclc Syst. Serv. Int. Digit. Libr. Perspect., Vol. 24, No. 3, Hal. 140-147, Jan 2008.

[31] C. Laurell, "A Spatial Approach To Social Media," Manag. Res. Rev., Vol. 40, No. 6, Hal. 671-683, Jan 2017.

[32] Z. Wu, J. Xie, X. Lian, Dan J. Pan, “A Privacy Protection Approach For Xml-Based Archives Management In A Cloud Environment," Electron. Libr., Vol. 37, No. 6, Hal. 970-983, Jan 2018.

[33] A. Gladkova Dan M. Ragnedda, "Exploring Digital Inequalities In Russia: An Interregional Comparative Analysis," Online Inf. Rev., Vol. 44, No. 4, Hal. 767-786, Jan 2020.

[34] C. M. Crawford, "Developing Webs Of Significance Through Communications: Appropriate Interactive Activities For Distributed Learning Environments," Campus-Wide Inf. Syst., Vol. 18, No. 2, Hal. 68-72, Jan 2001.

[35] G. Puia Dan J. Ofori-Dankwa, "The Effects Of National Culture And Ethno-Linguistic Diversity 
On Innovativeness," Balt. J. Manag., Vol. 8, No. 3, Hal. 349-371, Jan 2013.

[36] J. Bartle, "Political Awareness, Opinion Constraint And The Stability Of Ideological Positions," Polit. Stud., Vol. 48, No. 3, Hal. 467-484, Jun 2000.

[37] T. Stack, "In The Eyes Of The Law, In The Eyes Of Society: A Citizenship Tradition In West Mexico," Crit. Anthropol., Vol. 33, No. 1, Hal. 66-90, Feb 2013.

[38] M. Rovisco, "Staging Citizenship: Artistic Performance As A Site Of Contestation Of Citizenship," Int. J. Cult. Stud., Vol. 22, No. 5, Hal. 647-661, Jul 2019.

[39] J. A. Schlosser, "A Poetics Of American Citizenship: Blackness, Injury, And Claudia Rankine's Citizen," Law, Cult. Humanit., Vol. 16, No. 3, Hal. 432-453, Des 2016.

[40] M. Zhong Dan J. Zhang, "Analysis Of The Citizenship Education Of China's Junior High School Stage," Asian Educ. Dev. Stud., Vol. 4, No. 2, Hal. 190-203, Jan 2015.

[41] P. Alldred Dan N. J. Fox, "Assembling Citizenship: Sexualities Education, Micropolitics And The Becoming-Citizen," Sociology, Vol. 53, No. 4, Hal. 689-706, Feb 2019. 